\title{
SPEKTA
}

Jurnal Pengabdian Kepada Masyarakat : Teknologi dan Aplikasi

Journal homepage :

http://journal2.uad.ac.id/index.php/spekta

\section{[RETRACTED] PRE-SERVICE TEACHER EDUCATORS ASSESSMENT OF ADEQUACY OF GOOGLE CLASSROOM APPLICATION AS TEACHING TOOLS IN TEACHER EDUCATION PROGRAMME, NIGERIA}

\section{Bello Bolanle Muhinat}

Department of Social Sciences Education, Univerity of Ilorin, Nigeria

\begin{tabular}{l}
\hline ARTICLE INFO \\
\hline Retracted: notice to $:$ Pre-Service \\
Teacher Educators Assessment \\
Of Adequacy Of Google \\
Classroom Application As \\
Teaching Tools In Teacher \\
Education Programme, Nigeria”, \\
Vol 2 No 2, pp. 95-102. \\
DOI: $10.12928 /$ Spekta.v2i2.3961 \\
\hline
\end{tabular}

\begin{abstract}
Following a rigorous, carefully concerns and considered review of the article published in SPEKTA Journal to article entitled "PRE-SERVICE TEACHER EDUCATORS ASSESSMENT OF ADEQUACY OF GOOGLE CLASSROOM APPLICATION AS TEACHING TOOLS IN TEACHER EDUCATION PROGRAMME, NIGERIA" Vol 2, No 2, pp. 95-102, December 2022, DOI: 10.12928/Spekta.v2i2.3961
\end{abstract}

This paper has been found to be in violation of the SPEKTA Journal Publication principles and has been retracted.

The article contained redundant material, the editor investigated and found that the paper published in JURNAL JPSD (Jurnal Pendidikan Sekolah Dasar), Vol. 8, No. 2 (2021), pp. 41-48, URL: http://www.journal.uad.ac.id/index.php/JPSD/article/vie w/17968, entitled "PRE-SERVICE TEACHER EDUCATORS ASSESSMENT OF ADEQUACY OF GOOGLE CLASSROOM APPLICATION AS TEACHING TOOLS IN TEACHER EDUCATION PROGRAMME NIGERIA"

The document and its content has been removed from SPEKTA Journal and reasonable effort should be made to remove all references to this article.

\footnotetext{
* Corresponding author.

E-mail address: bello.mb@unilorin.edu.ng https://doi.org/10.12928/J.spekta.v2i2.3961
} 